\title{
Using Multiplier Analyses in Analyzing the Roles of Japanese Industrial Sectors
}

\author{
Ubaidillah Zuhdi, Teguh Herlambang, Nasori Nasori
}

\begin{abstract}
The purpose of this study is to analyze the roles of industrial sectors in the Japanese national economy by using simple output multiplier, and simple household income multiplier, the analysis tools in Input-Output (IO) analysis. The analysis period of the study is 2011. The results show that, on the period of analysis, manufacturing sector had the highest simple output multiplier value. Therefore, one can argue that an additional final demand for the sector would generate the most attractive effect to the Japanese economy by using the multiplier on the period of analysis. Conversely, the lowest value of the multiplier was owned by the real estate sector in 2011. On the other hand, from the point of view of simple household income multiplier, the highest value was owned by the construction sector on the analysis period. This result indicates that an additional yen of final demand for the sector would generate the highest new household income on the period of analysis. On the contrary, as with the previous multiplier, the real estate sector had the lowest simple household income multiplier value in 2011.
\end{abstract}

Keywords: Industrial sectors, National economy, IO analysis, Japan.

\section{INTRODUCTION}

There is no doubt that industry is an important aspect in the economy. Manufacturing, for example, has a role as an engine of growth until now [1]. In Romania, after 2000, the intensity of the process of deindustrialization decreased and this condition permitted manufacturing to remain the backbone of the Romanian industry and the overall economy [2].

Service sector has an important role in the economy too. It generates a direct and significant contribution to GDP and job creation, and provides critical inputs for the rest of the economy, thus having a significant impact on the overall investment condition, which is an essential factor of growth and development [3]. Besides, the sector is the biggest and fastest growing sector in the economy of the world, accounting the highest share in total output and employment in the most developed countries [4]. The contribution of service sector to GDP of India is $59.29 \%$, higher than primary (13.68\%) and secondary sectors $(27.03 \%)$ [5].

Above explanations show the previous studies that

Revised Manuscript Received on April 19, 2019.

Ubaidillah Zuhdi, (1) Department of Management, University of Nahdlatul Ulama Surabaya, Surabaya, Indonesia; (2) Department of Economic Sciences, Gdansk University of Technology, Gdansk, Poland. (Email: ubaidillah.zuhdi@unusa.ac.id.)

Teguh Herlambang, Department of Information System, University of Nahdlatul Ulama Surabaya, Surabaya, Indonesia. (Email: teguh@unusa.ac.id)

Nasori Nasori, (1) Department of Occupational Safety and Health, University of Nahdlatul Ulama Surabaya, Surabaya, Indonesia; (2) Department of Physics, Sepuluh Nopember Institute of Technology, Surabaya, Indonesia.( Email: nat.nasori@physics.its.ac.id)

investigate the roles of industrial sectors. The research focuses on overall industrial sectors especially in one specific country, however, is still needed. The research will generate a comprehensive view regarding the roles of industrial sectors in the economy of specific country. The current study is conducted in order to fulfill the gap on the topic in industry.

The purpose of the study is to analyze the roles of industrial sectors in the Japanese national economy. The study employs Input-Output (IO) analysis as an analysis tool. More specifically, the study uses simple output multiplier, and simple household income multiplier as analysis devices. The analysis period of the study is 2011 . The rest of this paper is described as follows. Section 2 scientifically explains the methodology of the study. Section 3 shows the results of calculations. The discussions for the results are also conducted on the section. The next section, section 4, describes the conclusions of the study, and suggested future studies.

\section{METHODOLOGY}

This section scientifically explains the methodology of the current study. The first step of the methodology is to describe the data used. The study uses the Japanese IO table for 2011 as data. The table consists of thirteen industrial sectors, and uses producer's price. The source of the data is [6]. The second step is to explain the Japanese industrial sectors used in this study. Table I shows those sectors.

The third step is to conduct the calculations using simple output multiplier, and simple household income multiplier. Reference [7] describes the equations of both multipliers as follows

$$
\begin{aligned}
& m(o)_{j}=\sum_{i=1}^{n} l_{i j} \\
& m(h)_{j}=\sum_{i=1}^{n} a_{n+1, i} l_{i j}
\end{aligned}
$$

The former model explains the simple output multiplier while the latter one describes the simple household income multiplier. More specifically, $m(o)_{j}, m(h)_{j}, a_{n+1, i}, n$, and $l_{i j}$ are simple output multiplier for sector $j$, simple household income multiplier for sector $j$, labor-input coefficients, the number of analyzed sectors, and a matrix of sector-to-sector multipliers, respectively. The next step is to analyze the roles of industrial sectors in the Japanese economy on the 
International Conference on Recents Advancements in Engineering and Technology (ICRAET-18) |15th and 16th March 2019|Siddhartha Institute of Technology \& Sciences, Telangana, India.

period of analysis. Conclusions of the study, and suggested further researches are described on the final step.

Table I. Japanese Industrial Sectors Used in this Study

\begin{tabular}{|c|l|}
\hline $\begin{array}{c}\text { Sector } \\
\text { Number }\end{array}$ & Sector Name \\
\hline 1 & $\begin{array}{l}\text { Agriculture, forestry, and } \\
\text { fishery }\end{array}$ \\
\hline 2 & Mining \\
\hline 3 & Manufacturing \\
\hline 4 & Construction \\
\hline 5 & $\begin{array}{l}\text { Electricity, gas, and water } \\
\text { supply }\end{array}$ \\
\hline 6 & Commerce \\
\hline 7 & Finance and insurance \\
\hline 8 & Real estate \\
\hline 9 & $\begin{array}{l}\text { Information } \\
\text { communications }\end{array}$ \\
\hline 10 & Public administration \\
\hline 11 & Services \\
\hline 12 & $\begin{array}{c}\text { Activities not elsewhere } \\
\text { classified }\end{array}$ \\
\hline 13 &
\end{tabular}

Source: [8]

\section{RESULTS AND FINDINGS}

Table II shows the top five Japanese industrial sectors viewed from the values of simple output multiplier. The analysis period of the table is 2011. Reference [7] explains that an output multiplier for sector $j$ is the total value of production in all industrial sectors of the economy that is needed in order to fulfill a currency's worth of final demand for the output of sector $j$. The reference also describes that, for the simple output multiplier, the total value of production is coming from the households exogenous model.

Table II. Top Five Japanese Industrial Sectors Viewed from the Values of Simple Output Multiplier, 2011

\begin{tabular}{|c|c|c|c|}
\hline No. & $\begin{array}{c}\text { Sector } \\
\text { Number }\end{array}$ & Sector Name & $\begin{array}{c}\text { Simple Output } \\
\text { Multiplier }\end{array}$ \\
\hline 1 & 3 & Manufacturing & 2.769 \\
\hline 2 & 5 & $\begin{array}{c}\text { Electricity, gas, } \\
\text { and water supply }\end{array}$ & 2.625 \\
\hline 3 & 4 & Construction & 2.268 \\
\hline 4 & 1 & $\begin{array}{c}\text { Agriculture, } \\
\text { forestry, and } \\
\text { fishery }\end{array}$ & 2.210 \\
\hline 5 & 2 & Mining & 2.181 \\
\hline
\end{tabular}

Based on the information in the table, manufacturing sector has the highest simple output multiplier value. The value is 2.769 . The value indicates that in order to satisfy a yen's worth of final demand for manufacturing sector's output, all Japanese sectors need to produce the products which the total value is $¥ 2.769$. One can argue that, by using the calculation results of simple output multiplier, an additional final demand for the sector would generate the most attractive effect to the economy of Japan on the analysis period.
Fig. 1 show the values of simple output multiplier of all Japanese industrial sectors used in this study. The figure uses 2011 as an analysis period too. On the analysis period, the lowest value was owned by the real estate sector. Based on the information in the figure, one can say that Japanese service sectors had the low values on the period of analysis.

On the other hand, Table III describes the top five Japanese industrial sectors viewed from the values of simple household income multiplier. As with the previous table, this table analyzes Japanese industrial sectors in 2011. The multiplier is applied to explain the economic impacts of new final demand as measured by new households income by using households exogenous model [7].

Based on the information in the table, the highest value is owned by the sector number 4 , construction. The value is 0.646. The value explains that, on the analysis period, an additional yen of final demand for the construction sector would generate $¥ 0.646$ of new household income, when all direct and indirect impacts were changed into yen estimates of income.

Fig. 2 describes the values of simple household income multiplier of Japanese industrial sectors in 2011. The interesting result can be seen on sector 8 , real estate. As with the previous multiplier, the sector had the lowest value on the analysis period from the point of view of simple household income multiplier. Therefore, one can argue that the sector was the most sluggish Japanese industrial sector on the period of analysis.

Previous study explains that, by using 89 Japanese industrial sectors, the most attractive sectors from the point of view of simple output multiplier for 1995, 2000, and 2005 were office supplies, office supplies, and motor vehicles, respectively [9]. On the other hand, another previous study shows that, by using 89 Japanese industrial sectors, and the point of view of simple household income multiplier, the most fascinating sectors for 1995, 2000, and 2005 were education, social security, and social security [10]. The current study provides the other point of view regarding the discussed aspects. One can say that the natural disasters happened in Japan in 2011 gave the important impacts on the emergence of the viewpoint.

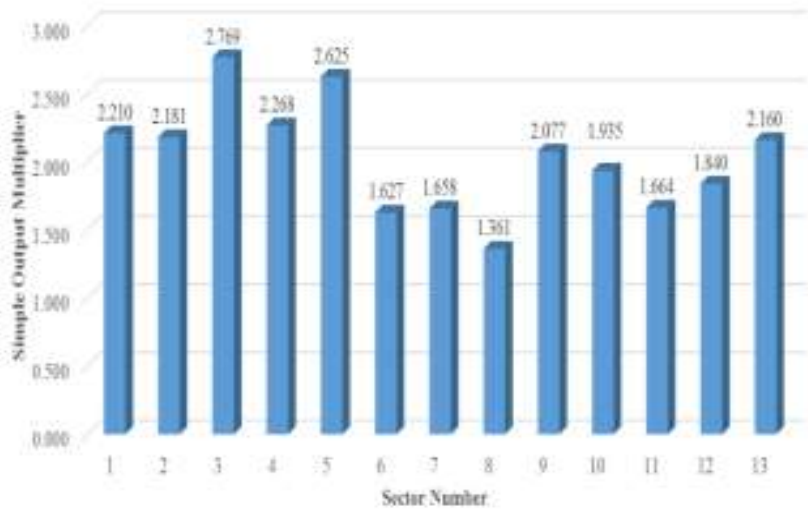

Figure 1. The Values of Simple Output Multiplier of Japanese Industrial Sectors, 2011 
Table III. Top Five Japanese Industrial Sectors Viewed from the Values of Simple Household Income Multiplier, 2011

\begin{tabular}{|c|c|c|c|}
\hline No. & $\begin{array}{c}\text { Sector } \\
\text { Number }\end{array}$ & Sector Name & $\begin{array}{c}\text { Simple } \\
\text { Household } \\
\text { Income } \\
\text { Multiplier }\end{array}$ \\
\hline 1 & 4 & Construction & 0.646 \\
\hline 2 & 12 & Services & 0.618 \\
\hline 3 & 9 & $\begin{array}{c}\text { Transport and } \\
\text { postal services }\end{array}$ & 0.560 \\
\hline 4 & 6 & $\begin{array}{c}\text { Commerce } \\
\text { Public }\end{array}$ & 0.554 \\
\hline 5 & 11 & administration & 0.543 \\
\hline
\end{tabular}

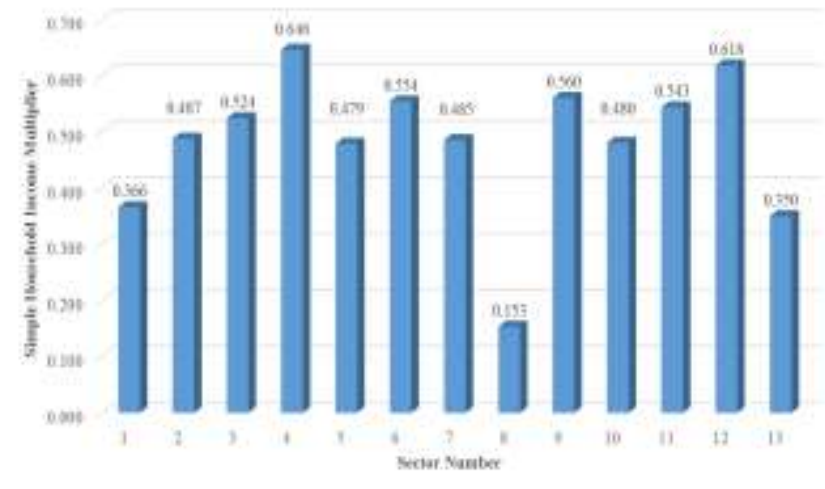

Figure 2. The Values of Simple Household Income Multiplier of Japanese Industrial Sectors, 2011

\section{CONCLUSIONS AND FURTHER RESEARCHES}

This study analyzes the roles of Japanese industrial sectors in the national economy by using IO analysis. More specifically, the current study employs simple output multiplier, and simple household income multiplier as analysis tools. The analysis period of the study is 2011 .

The results show that, on the period of analysis, manufacturing sector had the highest simple output multiplier value. Therefore, one can argue that an additional final demand for the sector would generate the most attractive effect to the Japanese economy by using the multiplier on the period of analysis. On the contrary, the lowest value of the multiplier was owned by the real estate sector in 2011.

On the other hand, from the point of view of simple household income multiplier, the highest value was owned by the construction sector on the analysis period. This result indicates that an additional yen of final demand for the sector would generate the highest new household income on the period of analysis. Conversely, as with the previous multiplier, the real estate sector had the lowest simple household income multiplier value in 2011.

The current study continues the previous studies in terms of analyzing the roles of Japanese industrial sectors in the national economy by using simple output multiplier, and simple household income multiplier. However, the study uses the aggregated 2011 Japanese IO table as data. One can argue that more detailed information, in terms of more detailed Japanese industrial sectors, will generate more detailed results. Therefore, as a further research, the study proposes the same discussion by using the disaggregated Japanese IO table for 2011.

The other suggested further research from the study is to extend the period of analysis, such as 1985-2011. This extension will generate a more comprehensive understanding of the roles of industrial sectors in the Japanese economy. For example, the extension will show the patterns of Japanese industrial sectors in terms of simple output multiplier and simple household income multiplier values.

\section{REFERENCES}

1. Szirmai, A. (2012). Industrialisation as an engine of growth in developing countries, 1950-2005. Structural change and economic dynamics, 23(4), 406-420.

2. Herman, E. (2016). The importance of the manufacturing sector in the Romanian economy. Procedia Technology, 22, 976-983.

3. DFID, U. The Contribution of Services to Development and the Role of Trade Liberalisation and Regulation.

4. Ahmed, A., \& Ahsan, H. (2011). Contribution of services sector in the economy of Pakistan. Working Papers \& Research Reports, 2011.

5. Singh, R. S. (2014). India's Service Sector-Shaping Future of Indian Retail Industry. Procedia Economics and Finance, 11, 314-322.

6. Ministry of Internal Affairs and Communications Japan (2016, September). 2011 Input-Output Tables for Japan. [Online]. Available: http://www.soumu.go.jp/main_content/000443188.pdf

7. Miller, R. E., \& Blair, P. D. (2009). Input-output analysis: foundations and extensions: Cambridge university press.

8. Zuhdi, U. (2017). An analysis of the characteristics of Japanese industrial sectors from 2005 through 2011. Paper presented at the IOP Conference Series: Earth and Environmental Science.

9. Zuhdi, U. (2014). The other perspective related to the role of information and communication technologies sectors in national economy: the case of Japan. Advanced Science Letters, 20(2), 483-486.

10. Zuhdi, U. (2015). An analysis of the role of information and communication technology sectors on Japanese national economy from 1995 through 2005: an application of multiplier analysis. Paper presented at the IOP Conference Series: Earth and Environmental Science.

\section{AUTHORS PROFILE}

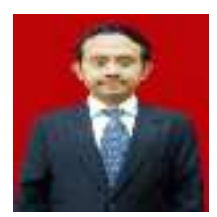

Ubaidillah Zuhdi is currently a Lecturer at the Department of Management, University of Nahdlatul Ulama Surabaya. He earned a Doctorate of Engineering at Tokyo University of Science in 2015. He received his M.Eng. degree at the same university in 2011. He was a Lecturer at the Department of Economic Sciences, Gdansk University of Technology from 2015 through 
2018. He is currently a Head of Journal Sector at University of Nahdlatul Ulama Surabaya. He has published over 20 peer-reviewed papers. His research interests include (1) the economic analyses of the sectors of Information and Communication Technology (ICT), creative industry, livestock, agriculture, energy, and fishery, (2) applied economics, (3) policy analysis, (4) IO analysis, and (5) mathematical modeling. He is a reviewer of many reputable journals, such as International Journal of General Systems and Economic Systems Research.

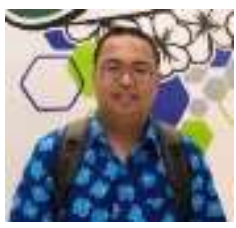

Teguh Herlambang is currently a Lecturer at the Department of Information System, University of Nahdlatul Ulama Surabaya. He received his B.Sc. and M.Sc. degrees at the Department of Mathematics, Sepuluh Nopember Institute of Technology in 2010 and 2012, respectively. $\mathrm{He}$ received his Ph.D. degree at the Department of Ocean Engineering at Sepuluh Nopember Institute of Technology in 2016. He is currently a Head of Research Sector at University of Nahdlatul Ulama Surabaya. He is also assigned as a researcher at Center of Excellence for Mechatronics and Industrial Automation PUI-PT MIA-RC) of Sepuluh Nopember Institute of Technology by Kemenristekdikti. His research areas are modelling, applied mathematics, navigation, guidance, and control of dynamics system.

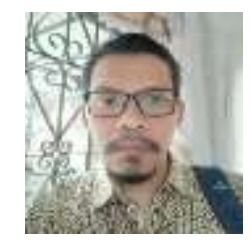

Nasori obtained his Ph.D. in Mathematic and Natural Science from the 3D Nanostructure Department, Ilmenau University of Technology in 2018. Till now, he works as a Lecturer at the Department of Physics, Sepuluh Nopember Institute of Technology, and the Department of Occupational Safety and Health, University of Nahdlatul Ulama Surabaya. His current researches focus on the design and fabrication of functional nanostructures for PEC water splitting, medical physics, and biophysics. 